\title{
Korelasi antara Neutrophyl Lymphocyte Ratio dengan Stadium Kanker pada Pasien Kanker Payudara
}

\author{
Correlation Between Neutrophyl Lymphocyte Ratio with Cancer Stage in Breast Cancer Patients
}

\author{
Irma Ningsih Yuvita Fallo, Rina. A. Sidharta, Lucia Sincu Gunawan* \\ Fakultas Ilmu Kesehatan, Universitas Setia Budi Surakarta \\ *Corresponding author: sincugunawan@gmail.com
}

\begin{abstract}
ABSTRAK
Kanker payudara merupakan salah satu kanker penyebab kematian pada wanita. Banyak wanita yang menyadari terserang kanker payudara setelah kanker masuk pada stadium lanjut, sehingga tidak ada proses deteksi dini yang dapat meningkatkan peluang kesembuhan dengan tata laksana di awal penyakit. Stadium kanker payudara meliputi; Stadium I, II, IIIA, IIIB dan IV. Peningkatan Neutrophi lLymphocyte Ratio (NLR) dikaitkan dengan peningkatan kematian pada keganasan kanker payudara.Tujuan penelitian ini adalah untuk mengetahui korelasi antara NLR dengan stadium kanker pada pasien kanker payudara.

Teknik pengambilan sampel pada penelitian ini adalah concecutive sampling. Pasien diambil sesuai dengan kriteria inklusi dan eksklusi, diurutkan sampai jumlah sampel terpenuhi. Besar sampel pada penelitian ini adalah 55 sampel. Waktu penelitian dilakukan pada bulan April - Juni 2018 di Rumah Sakit Umum Daerah Dr. Moewardi di Surakarta. Sumber data penelitian ini adalah data sekunder yang diperoleh dari rekam medis laboratorium Patologi Klinik dan laboratorium Patologi Anatomi pasien yang terdiagnosis kanker payudara dan teknik analisis data menggunakan uji Kolmogorov Smirnov kemudian dilanjutkan dengan uji Spearman.

Hasil penelitian yang diperoleh menunjukkan correlation coefficient (r) sebesar 0,350, probabilitas (p) sebesar 0,009. Maka, nilai ini menunjukkan korelasi yang lemah, positif dan bermakna antara NLR dengan stadium kanker payudara. Perlu dilakukan penelitian selanjutnya menggunakan data primer, sehingga dapat mengetahui faktor-faktor yang mempengaruhi peningkatan NLR.
\end{abstract}

Kata Kunci : Neutrophyl Lymphocyte Ratio, Stadium kanker, Kanker payudara

\section{ABSTRACT}

Breast cancer is one of the leading causes of death in women. Many women are aware of breast cancer after cancer comes in an advanced stage, so there is no early detection process that can increase chance of recovery with early management. Stage of breast cancer includes stage I, II, IIIA, IIIB and IV. Neutrophyl lymphocyte ratio (NLR) associated with increasing mortality in breast cancer patients. The purpose of this study was to determine the correlation between NLR with cancer stage in breast cancer patients.

The sampling technique in this research is concecutive sampling. Patients were taken according to the inclusion and exclusion criteria, sorted until the number of samples was met. The sample size in this study was 55 samples. The time of the study was conducted in April to June 2018 at Regional General Hospital Dr. Moewardi in Surakarta. The date source of this research is secondary date obtained from medical records of patients diagnosed with breast cancer and date analysis techniques using Kolmogorov Smirnov test and then followed by Spearman test.

The results obtained showed correlation coefficient ( $r$ ) of 0.350, probability (p) of 0,009. This value shows a weak, positive and meaningful correlation between NLR and stage of breast cancer. Further research needs to be done using primary date, so that it can determine the factors that influence the increase in NLR.

Keywords : Neutrophyl Lymphocyte Ratio, Stage of cancer, Breast cancer.

\section{PENDAHULUAN}

Kanker payudara merupakan salah satu kanker penyebab kematian pada wanita. Banyak wanita menyadari terserang kanker payudara setelah kanker masuk pada stadium lanjut, sehingga tidak ada proses deteksi dini yang dapat memperlambat atau bahkan menyembuhkan kanker tersebut (Savitri et al., 2015).

Kanker payudara menempati urutan pertama sebagai jenis kanker yang paling umum 
diderita oleh wanita di dunia. Kanker payudara mengambil bagian seperempat total kasus baru kanker secara keseluruhan yang terdiagnosis pada tahun 2012 (Globocan, 2013). Prevalensi kanker payudara di Indonesia cukup tinggi dan merupakan jenis kanker yang paling mendominasi di Indonesia. Berdasarkan data dari sistem informasi rumah sakit (SIRS) tahun 2007, kanker payudara menempati urutan pertama pada pasien rawat inap di seluruh rumah sakit di Indonesia (16,85 \%). Sedangkan pada tahun 2010, kasus rawat inap kanker payudara 12.014 kasus $(28,7 \%)$ (Depkes RI, 2014). Prevalensi kanker payudara berdasarkan wawancara sebanyak 1,4\%o dan yang tertinggi terdapat di Yogyakarta $(4,1 \%)$, diikuti Jawa Tengah (2,1\%o) (Riskesdas, 2013). Di Jawa Tengah jumlah penderita kanker payudara menduduki peringkat pertama mencapai 12.281 kasus $(50,74 \%)$, dengan populasi penderita tertinggi di Surakarta (Dinas Kesehatan Jawa Tengah, 2009).

Kanker payudara menyebabkan perubahan bentuk payudara, ukuran payudara dan perubahan pada puting susu. Bentuk dan ukuran salah satu payudara terlihat berubah, bisa lebih kecil atau lebih besar daripada payudara sebelahnya dan terlihat turun. Puting susu terasa seperti terbakar, gatal dan muncul luka yang sulit atau lama sembuh, puting terlihat tertarik masuk ke dalam (retraksi), berubah bentuk atau posisi, dan memerah (Savitri et al., 2015).

Neutrofil merupakan salah satu penyusun infiltrat sel inflamasi yang dijumpai dalam berbagai kanker pada manusia. Limfosit merupakan komponen penting dari sistem imun adaptif dan infiltrasi limfosit menunjukkan adanya respon imun seluler anti kanker yang efektif. Nilai Neutrophyl Lymphocyte Ratio (NLR) memiliki nilai prognosis dan berhubungan dengan harapan hidup pasien dengan berbagai tipe kanker (Akuntanto, 2014).

Peningkatan NLR dikaitkan dengan peningkatan kematian pada keganasan kanker payudara. Mengukur efek NLR berhubungan dengan kelangsungan hidup pada pasien kanker payudara (Ethier et al., 2017). Penelitian yang dilakukan oleh Azab et al. (2011) menunjukkan bahwa pasien kanker payudara dengan nilai NLR > 3,3 memiliki angka kematian lebih tinggi dibandingkan dengan pasien dengan nilai NLR $<1,8$. Penelitian yang dilakukan oleh Prasetyo et al. (2015) menunjukkan bahwa nilai NLR dapat digunakan untuk menilai perkembangan kanker payudara, semakin lanjut kondisi kanker payudara (tahapan IV atau metastasis) semakin tinggi nilai NLR.

Berdasarkan uraian di atas, peneliti tertarik untuk melakukan penelitian dengan judul "Korelasi antara Neutrophyl Lymphocyte Ratio dengan Stadium Kanker pada Pasien Kanker Payudara".

Tujuan penelitian ini untuk mengetahui korelasi antara NLR dengan stadium kanker pada pasien kanker payudara. Manfaat penelitian bagi peneliti adalah penelitian ini dapat menambah wawasan mengenai korelasi antara NLR dengan stadium kanker pada pasien kanker payudara.

Hipotesis penelitian ini adalah terdapat korelasi antara NLR dengan stadium kanker pada pasien kanker payudara.

\section{METODE PENELITIAN}

Penelitian ini adalah penelitian observasional analitik. Rancangan penelitian yang digunakan adalah cross sectional. Data sampel penelitian diambil dari data rekam medis yaitu hasil pemeriksaan neutrophyl dan lymphocyte dari laboratorium Patologi Klinik dan pasien yang telah terdiagnosis kanker payudara secara histopatologi oleh instalasi laboratorium Patologi Anatomi Rumah Sakit Umum Daerah (RSUD) Dr Moewardi (RSDM) di Surakarta. Waktu penelitian dilakukan pada bulan April Juni 2018. Jumlah sampel dalam penelitian ini adalah sebanyak 55 subjek. Teknik sampling yang digunakan dalam penelitian ini adalah 
concecutive sampling. Pasien diambil sesuai dengan kriteria inklusi dan ekslusi, diurutkan sampai jumlah sampel terpenuhi.

Kriteria inklusi subjek penelitian meliputi :

1. Pasien wanita kanker payudara berusia $\geq 18$ tahun yang sudah didiagnosis oleh klinisi

2. Terdiagnosis kanker payudara secara histopatologi

3. Belum kemoterapi, radiasi dan operasi.

Kriteria eksklusi subjek penelitian meliputi : pasien menderita keganasan hematologi

Data karakteristik subjek penelitian disajikan dalam bentuk deskriptif. Uji statistik Kolmogorov Smirnov untuk mengetahui distribusi data. Dilanjutkan dengan Uji Spearman karena data tidak terdistribusi normal.

\section{HASIL DAN PEMBAHASAN}

Subjek penelitian ini adalah pasien yang terdiagnosis kanker payudara secara histopatologi oleh instalasi laboratorium Patologi Anatomi RSDM di Surakarta. Subjek penelitian sebanyak 55 sampel yang diperoleh dari data sekunder laboratorium Patologi Klinik dan laboratorium Patologi Anatomi selama periode Januari 2018 sampai Februari 2018. Berikut adalah hasil penelitian meliputi uji kualitas internal (presisi dan akurasi), karakteristik pemeriksaan, serta uji hipotesis penelitian yang telah dilakukan.

\section{Uji Kualitas Internal}

Uji kualitas internal digunakan untuk mengetahui mutu atau kualitas hasil pemeriksaan secara internal. Uji kualitas internal meliputi uji presisi atau ketelitian dan uji akurasi atau ketepatan.

a. Uji Presisi atau Ketelitian

Nilai presisi menunjukkan seberapa dekat suatu hasil pemeriksaan bila dilakukan berulang dengan sampel yang sama. Presisi terutama dipengaruhi oleh kesalahan acak yang tidak dapat dihindari. Presisi biasanya dinyatakan dalam nilai koefisien variasi ( $\% \mathrm{KV}$ atau $\% \mathrm{CV}$ ) yang dihitung dengan rumus berikut :

$$
\mathrm{KV}(\%)=\frac{\mathrm{SD} \times 100}{\bar{x}}
$$

Keterangan :

$\mathrm{KV}=$ Koefisien Variasi

$\mathrm{SD}=$ Standar Deviasi (simpangan baku)

$\bar{x}=$ Rata-rata hasil pemerisaan berulang

(Depkes, 2008)

b. Uji Akurasi atau Ketepatan

Akurasi (ketepatan) digunakan untuk meni-

Tabel 1. Hasil Uji Presisi atau Ketelitian

\begin{tabular}{ccccc}
\hline $\begin{array}{c}\text { Parameter Pemeriksaan } \\
\text { (Satuan) }\end{array}$ & $\begin{array}{c}\text { Rerata } \\
\text { Kadar }\end{array}$ & SD & KV (\%) & $\begin{array}{c}\text { KV (\%) } \\
\text { Max }\end{array}$ \\
\hline Neutrophyl (\%) & & & & \\
Lot A 1035 & 57,32 & 2,58 & 4,50 & 8,55 \\
Lot A 3035 & 70,67 & 3,10 & 4,39 & \\
Lymphocyte (\%) & & & & \\
Lot A 1035 & 27,32 & 2,89 & 10,56 & 15 \\
Lot A 3035 & 17,73 & 0,98 & 5,50 & \\
Leukosit (/ $\mu$ L) & & & & \\
Lot A 1035 & 3,48 & 0,07 & 2,00 & 15 \\
Lot A 3035 & 16,72 & 0,36 & 2,14 & \\
\hline
\end{tabular}

Sumber : (Vis JY \& Huisman A, 2016 \& Depkes, 2008).

Keterangan : $\mu \mathrm{L}=$ Mikro liter, $\mathrm{SD}=$ Standar deviasi, $\mathrm{KV}=$ Koefisien variasi, Max : Maksimal.

Tabel 2. Hasil Uji Akurasi atau Ketepatan

\begin{tabular}{lllll}
\hline $\begin{array}{l}\text { Parameter } \\
\begin{array}{l}\text { Pemeriksaan } \\
\text { (Satuan) }\end{array}\end{array}$ & $\begin{array}{l}\text { Kadar Pemeriksaan/ } \\
\text { Rujukan (Rerata/ } \\
\text { Rentang 2 SD) }\end{array}$ & Rerata & Simpulan & d\% \\
\hline Neutrophyl $(\%)$ & $56,1(41,1-71,1)$ & 57,32 & Masuk dalam rentang & $-0,05$ \\
Lymphocyte $(\%)$ & $28,9(13,9-43,9)$ & 27,32 & Masuk dalam rentang & 0,02 \\
Leukosit $(/ \mu \mathrm{L})$ & $3,44(2,765-4,115)$ & 3,48 & Masuk dalam rentang & 0,01 \\
\hline
\end{tabular}

Sumber : (Insert Kit Advia, 2018).

Keterangan : $\mu \mathrm{l}=$ Mikro liter, $\%=$ Persen, $\mathrm{d} \%=$ Nilai bias, $\mathrm{SD}=$ Standar deviasi. 
Tabel 3. Karakteristik Subjek Dasar Penelitian

\begin{tabular}{lcc}
\hline Variabel & n (\%) & Median (min-maks) \\
\hline Usia (tahun) & & \\
$\quad<50$ & $21(38,2)$ & \\
$\geq 50$ & $34(61,8)$ & \\
Leukosit $(/ \mu \mathrm{L})$ & & 7,8345 \\
Neutrophyl & & \\
$\%$ & & 63,5378 \\
$/ \mu \mathrm{L}$ & & $4,977,55$ \\
Lymphocyte & \\
$\%$ & & 25,7576 \\
$/ \mu \mathrm{L}$ & & $2,017,85$ \\
\hline
\end{tabular}

Keterangan $: / \mu \mathrm{L}=$ per mikro liter, $\%=$ Persen, $\mathrm{n}=$ Jumlah, Min $=$ Minimal, Maks $=$ Maksimal.

Tabel 4. Hasil Uji Normalitas

\begin{tabular}{lcl}
\hline Variabel & $\mathbf{P}$ & Keterangan \\
\hline NLR & 0,001 & Tidak normal \\
Stadium Kanker & 0,001 & Tidak normal \\
\hline
\end{tabular}

Keterangan : Uji distribusi normal dengan Kolmogorov-Smirnov, jika p >0,05, maka data terdistribusi normal.

Tabel 5. Uji Normalitas (Sesudah ditransformasi)

\begin{tabular}{lcc}
\hline Variabel & $\mathbf{P}$ & Keterangan \\
\hline NLR & 0,003 & Tidak normal \\
Stadium Kanker & 0,001 & Tidak normal \\
\hline
\end{tabular}

Keterangan : Uji distribusi normal sesudah ditransformasi, jika $\mathrm{p}>0,05$, maka data terdistribusi normal.

lai adanya kesalahan acak atau sistematik atau keduanya (total). Nilai akurasi menunjukkan kedekatan hasil terhadap nilai sebenarmya yang akan ditentukan oleh metode standar. Akurasi dapat dinilai dari hasil pemeriksaan bahan kontrol dan dihitung sebagai nilai biasnya $(\mathrm{d} \%)$ :

$$
d(\%)=\frac{x-N A}{N A}
$$

Keterangan :

$\mathrm{d} \%=$ Nilai Bias

$\mathrm{x}=$ Hasil pemeriksaan bahan kontrol

$\mathrm{NA}=$ Nilai aktual / sebenarnya dari bahan kontrol

Nilai d (\%) dapat positifatau negatif

Nilai positif menunjukkan nilai yang lebih tinggi dari seharusnya.

Nilai negatif menunjukkan nilai yang lebih rendah dari seharusnya (Depkes, 2008).

\section{Karakteristik subjek penelitian}

Tabel 3 menunjukkan bahwa subjek penelitian yang berusia $<50$ tahun sebanyak 21 orang $(38,2 \%)$ dan subjek penelitian yang berusia $\geq 50$ tahun sebanyak 34 orang $(61,8 \%)$. Hasil median (min-maks) untuk total leukosit subjek pene- litian adalah 7,8345/ $\mu \mathrm{L}$. Hasil median (minmaks) neutrophyl subjek penelitian adalah $63,5378 \%$ dan $4,977,55 / \mu \mathrm{L}$. Hasil median (minmaks) lymphocyte subjek penelitian adalah $25,7576 \%$ dan $2,017,85 / \mu \mathrm{L}$.

\section{Uji Normalitas Data}

Data hasil penelitian yang diperoleh kemudian dianalisis untuk membuktikan adanya korelasi antara NLR dengan stadium kanker payudara, maka dilakukan uji normalitas. Uji normalitas ini dilakukan untuk melihat apakah data hasil pengukuran antara NLR dan stadium kanker payudara terdistribusi normal atau tidak. Uji normalitas data menggunakan uji One-Sample KolmogorovSmirnov Test, apabila nilai $\mathrm{p}>0,05$, maka data dalam distribusi normal, tetapi jika nilai $\mathrm{p}<0,05$, maka data dalam distribusi tidak normal. Hasil uji normalitas ditunjukkan di Tabel 4.

Dari data uji One-Sample KolmogorovSmirnov pada Tabel 4 diperoleh nilai probabilitas (p) NLR adalah 0,001. Nilai probabilitas stadium kanker adalah 0,001 . Nilai probabilitas NLR dan stadium kanker tidak melebihi taraf 
Tabel 6. Interpretasi Kekuatan Korelasi

\begin{tabular}{lll}
\hline Parameter & \multicolumn{1}{c}{ Nilai } & \multicolumn{1}{c}{ Interpretasi } \\
\hline Kekuatan korelasi (r) & $0,00-0,199$ & Sangat lemah \\
& $0,20-0,399$ & Lemah \\
& $0,40-0,599$ & Sedang \\
& $0,60-0,799$ & Kuat \\
& $0,80-1,000$ & Sangat kuat \\
\hline Nilai p & $\mathrm{p}<0,05$ & Terdapat korelasi yang bermakna antara \\
& & dua variabel yang di uji. \\
& & Tidak terdapat korelasi yang bermakna \\
& & antara dua variabel yang di uji. \\
\hline Arah korelasi & $(+)$ Positif & Searah, semakin besar nilai suatu variabel \\
& & semakin besar pula nilai variabel lainnya. \\
& & Berlawanan arah, semakin besar ni lai satu \\
& $(-)$ Negatif & variabel, semakin kecil nilai variabel \\
& & lainnya. \\
\hline
\end{tabular}

Sumber : (Dahlan, 2013).

Tabel 7. Korelasi NLR Dengan Stadium Kanker Payudara

\begin{tabular}{llcccc}
\hline Variabel & & $\mathbf{n}(\mathbf{\%})$ & $\begin{array}{c}\text { Median } \\
\text { (min-maks) }\end{array}$ & $\mathbf{P}$ & $\mathbf{R}$ \\
\hline NLR & & & 2,45 & & \\
Stadium kanker & Stadium I & $2(3,6)$ & & $\mathbf{0 , 0 0 9}$ & $\mathbf{0 , 3 5 0}$ \\
& Stadium II & $14(25,5)$ & & & \\
& Stadium III & $39(70,9)$ & & & \\
& Stadium IV & 0 & & & \\
\hline
\end{tabular}

Keterangan : NLR $=$ Neutrophyl lymphocyte ratio, $\mathrm{p}<0,05=$ Bermakna, $\mathrm{r}=$ Uji korelasi Spearman .

signifikansi 5\% $(\mathrm{p}<0,05)$, sehingga data tidak terdistribusi normal. Karena data tidak terdistribusi normal, maka dilakukan uji transformasi data, sehingga didapatkan hasil di Tabel 5.

Dari data uji One-Sample KolmogorovSmirnov pada Tabel 5 diperoleh nilai probabilitas (p) $\log$ NLR adalah 0,003 dan nilai probabilitas log stadium kanker payudara adalah 0,001. Nilai probabilitas pada NLR dan stadium kanker payudara tersebut tidak melebihi taraf signifikansi 5\% $(\mathrm{p}<0,05)$, sehingga data tidak terdistribusi normal, dilanjutkan pengujian hipotesis dan digunakan analisis menggunakan uji statistik korelasi Spearman.

\section{Analisis Data}

Analisis data dilakukan untuk melihat apakah terdapat korelasi hasil yang bermakna antara NLR dengan stadium kanker payudara. Analisis menggunakan uji statistik korelasi Spearman. Berikut dapat dilihat interpretasi kekuatan korelasi pada Tabel 6
Uji Spearman dllakukan untuk mengetahui apakah terdapat korelasi antara NLR dengan stadium kanker payudara. Hasil uji Spearman ditunjukkan di Tabel 7.

Berdasarkan output di atas diketahui bahwa nilai probabilitas (p) adalah 0,009 dan nilai hasil correlation coefficient (r) adalah 0,350. Maka, nilai ini menandakan korelasi yang positif, lemah dan bermakna antara NLR dengan stadium kanker payudara.

Penelitian ini dilakukan pada 55 subjek yang terdiri dari usia $<50$ tahun sebanyak 21 orang dan usia $\geq 50$ tahun sebanyak 34 orang. Semakin bertambahnya usia meningkatkan risiko kanker payudara. Wanita paling sering terserang kanker payudara adalah usia diatas 40 tahun. Wanita berusia di bawah 40 tahun juga dapat terserang kanker payudara, namun risikonya lebih rendah dibandingkan wanita diatas 40 tahun. Penelitian Octaviana (2011) yang berjudul "Faktor-faktor Risiko Kanker Payudara pada Pasien Kanker Payudara Wanita di Rumah Sakit Kanker Dharmais Jakarta" menyatakan bahwa kelom- 
pok kasus kanker payudara banyak terdapat pada rentang usia 40-49 tahun yaitu sebesar 41,7\%, kemudian pada rentang usia 50-59 tahun yaitu sebesar 37,5\%.

Subjek penelitian dikelompokkan berdasarkan stadium kanker payudara, yaitu stadium I sebanyak 2 orang, stadium 2 sebanyak 14 orang, stadium III sebanyak 39 orang dan stadium IV 0 orang. Penelitian Hartono et al. (2015) tentang penilaian jumlah neutrofil dan limfosit sebelum dan setelah terapi pada penderita karsinoma payudara sebanyak 43 pasien, menyatakan bahwa dari keseluruhan sampel, yang terbanyak ialah kanker payudara stadium IIIB yaitu 25 pasien (58,1\%), diikuti oleh stadium IIIC $(25,6 \%)$, stadium IIIA $(11,6 \%)$ dan stadium IV $(4,7 \%)$. Dari hasil pemantauan selama periode 1 tahun diperoleh 40 pasien yang hidup dan 3 pasien yang meninggal dunia akibat metastasis atau komplikasi.

Rumah Sakit Umum Daerah Dr Moewardi merupakan rumah sakit rujukan terakhir di Surakarta. Pasien kanker payudara yang dirujuk kebanyakan sudah memasuki stadium III. Prasetyo et al. (2015) melakukan penelitian dengan judul "Angka banding neutrofil/limfosit di karsinoma payudara". penelitian tersebut melibatkan 130 pasien kanker payudara. Penelitian tersebut menunjukkan bahwa rata-rata pasien kanker payudara $(79,2 \%)$ memeriksakan payudaranya setelah terjadi penyebaran di kulit, dinding dada atau keduanya dan yang bersangkutan memeriksakan keadaannya setelah penyakit sampai ke stadium III (54,6\%). Hasil penelitian tersebut disimpulkan terdapat korelasi yang lemah antara NLR dengan stadium kanker payudara.

Penelitian yang dilakukan oleh Akuntanto (2014) tentang hubungan rasio neutrofil terhadap limfosit dengan stadium klinis pada karsinoma nasofaring menunjukkan hasil adanya hubungan bermakna antara NLR dengan stadium klinis pada karsinoma nasofaring $(\mathrm{p}<0,05)$. Arah hubungan yang ditunjukkan adalah positif, artinya bahwa semakin tinggi NLR, maka stadium klinis juga semakin tinggi pada karsinoma nasofaring sedangkan semakin rendah NLR, maka stadium klinis juga semakin rendah.

Ethier et al. (2017) melakukan penelitian dengan judul "Prognostic role of neutrophil-tolymphocyte ratio in breast cancer: a systematic review and meta-analysis". Penelitian tersebut melibatkan 8563 pasien. Penelitian menggunakan nilai cut off yang berbeda untuk mengklasifikasikan NLR tinggi (kisaran 1,9-5,0). Nilai cut off median untuk NLR tinggi yang digunakan adalah 3,0. Di mana NLR lebih tinggi dari nilai cut off terkait dengan kelangsungan hidup pasien yang buruk.

Guthrie et al. (2013) melakukan systematic reviews pada 12 penelitian dengan 2156 pasien untuk mengetahui nilai prognosis NLR pada pasien kanker yang menjalani kemoterapi atau radioterapi. Tiga penelitian, yang terdiri atas 579 pasien, meneliti nilai prognosis dari NLR pada pasien dengan kanker kolorektal yang menjalani kemoterapi. Neutrofil limfosit rasio tersebut memiliki nilai prognosis independen terhadap stadium tumor baik pada overall dan diseasefree survival pada semua penelitian. Lima penelitian lainnya yang terdiri atas 1113 pasien melaporkan nilai prognosis pada pasien dengan keganasan toraks yang menjalani kemoterapi. Nilai NLR pra terapi secara konsisten memiliki nilai prognosis, baik untuk disease-free survival dan overall survival.

Penelitian yang dilakukan oleh Sambasivaiah et al. (2005) tentang hitung jenis sel darah dan pola sitokin pada 36 pasien kanker. Penelitian tersebut melibatkan pasien kanker leher rahim, paru-paru, payudara, hati, kolon, esofagus, kepala leher dan pankreas. Neutrofil limfosit rasio pada pasien kanker terbukti lebih tinggi dibandingkan NLR kelompok kontrol dan NLR pasien kanker stadium lanjut terbukti lebih tinggi dibandingkan dengan NLR pasien kanker stadium awal. Hal ini menunjukkan bahwa NLR 
memiliki korelasi dengan stadium klinis pasien kanker.

Keterbatasan penelitian ini adalah menggunakan data sekunder sehingga peneliti tidak mengetahui kondisi atau faktor-faktor yang mempengaruhi peningkatan NLR, misalnya infeksi, alergi dan inflamasi.

\section{KESIMPULAN}

Terdapat korelasi yang lemah, positif dan bermakna antara Neutrophyl Lymphocyte Ratio dengan Stadium Kanker pada Pasien Kanker Payudara $(\mathrm{r}=0,350$ dan $\mathrm{p}=0,009)$.

Neutrophyl Lymphocyte Ratio digunakan untuk menilai perkembangan penyakit kanker payudara. Perlu penelitian lanjutan menggunakan data primer, sehingga diketahui faktorfaktor yang mempengaruhi peningkatan NLR, misalnya infeksi, alergi dan inflamasi.

\section{DAFTAR PUSTAKA}

Akuntanto, I.A. 2014. Hubungan Rasio Netrofil terhadap Limfosit dengan Stadium Klinis pada Karsinoma Nasofarings. Thesis. Pasca Sarjana. Universitas Gadjah Mada. Yogyakarta

Azab, B, Bhatt, V.R., Phookan, J., Murukutla, S., Kohn, N. 2012. Usefulness of the Neutrophil-to-lymphocyte ratio in predicting short and long term mortality in breast cancer patients. Annals of Surgical Oncology. 19(1), 217-224. http://link.springer.com/article/10.1245/s10434-011-18140 .
Dahlan, M. 2009. Besar Sampel dan Cara Pengambilan Sampel Dalam Penelitian Kedokteran dan Kesehatan. Salemba Medika. Jakarta.

Departemen Kesehatan RI. 2008. Pedoman Praktik Laboratorium Kesehatan yang Benar $=($ Good laboratory practice). Departemen Kesehatan. Jakarta.

Dinkes Jawa Tengah. 2009. Profil Kesehatan Dinas Provinsi Jawa Tengah Tahun 2009. Dinkes Jawa Tengah. Semarang.

Ethier, J., Desautels, D, Templeton, A, Shah, P.S, Amir, E. 2017. Prognostic role of neutrophil-to-lymphocyte ratio in breast cancer: a systematic review and meta-analysis. Breast Cancer Research, 19(2), 1-13.

Guthrie G.J., Charles, K.A, Roxburgh, C.S, Horgan, P.G, McMIllan, D.C. 2013. The Systemic Inflammation based neutrophil lymphocyte ratio: Experience in patients with cancer. Critical Review in Oncology/Hematology. 88: 218230.

Hartono, B., Pontoh, V, \& Merung, M. 2015. Penilaian Jumlah Neutrofil, Limfosit Dan Trombosit, Kadar Protein C, Kadar Albumin, Rasio Neutrofil Limfosit, Serta Rasio Trombosit Limfosit Sebelum dan Setelah Terapi Pada Penderita Karsinoma Payudara. Biomedik, 7(3), 163-170.

Prasetyo, Y.E., Bahrun, U, Pakasi, R.D.N 2015. Angka Banding Neutrofil/Limfosit di Karsinoma Payudara. Indonesian Journal of Clinical Pathology and Medical Laboratory, 21(2), 125-129.

Riset Kesehatan Dasar (Riskesdas). 2013. Pedoman Pewawancara Petugas Pengumpul Data. Badan Litbangkes. Jakarta.

Sambasivaiah, K., Kumaraswamy, R., Rao, S., Phaneendra, B.V., Ay, S.K.L., Sarma, K.V.S. 2005. Blood Cell Types and Cytokines Patterns in Solid Tumours Patients. Indian $J$ Pediatr Oncology, 26(2), 19-24.

Savitri, A., Larasati, A., Utami, E.D.R. 2015. Kupas Tuntas Kanker Payudara Leher Rahim dan Rahim. Pustaka Baru Press. Yogyakarta. 